\title{
Problemy kompatybilności rop naftowych
}

\section{Crude oil compatibility problems}

\author{
Wojciech Krasodomski, Beata Altkorn, Anna Duda, Sławomir Szuflita, Michał Krasodomski \\ Instytut Nafty i Gazu - Państwowy Instytut Badawczy
}

\begin{abstract}
STRESZCZENIE: Ropy naftowe przetwarzane w rafineriach są złożoną mieszaniną węglowodorów, w której rozpuszczone lub zawieszone są związki heteroorganiczne. Tego rodzaju układy cechuje zwykle pewna niestabilność, związana z możliwością wytrącania się struktur wielofazowych zależnych od charakteru chemicznego składników ropy. Zjawiska te wpływają niekorzystnie na przebieg procesów rafineryjnych. Tworzące się zawiesiny, a w konsekwencji osady, związane ze zmianą charakteru chemicznego środowiska - mieszanki węglowodorów pochodzących z rop naftowych, mogą blokować infrastrukturę rafinerii - zbiorniki i rurociągi - a także wymienniki ciepła. Osady te można przeprowadzić do fazy ciekłej, jedynie zwiększając jej polarność. Aby zatem nie dopuścić do termicznie nieodwracalnych zjawisk peptyzacji i sedymentacji struktur i agregatów asfaltenowo-żywicznych, konieczna jest możliwie precyzyjna ocena kompatybilności przetwarzanych rop podczas komponowania wsadu. W prezentowanej pracy zestawiono informacje dotyczące zarówno praktycznych, jak i teoretycznych aspektów kompatybilności rop naftowych. Omówiono zasady klasyfikacji rop naftowych, współczesne poglądy na budowę struktur koloidalnych zawieszonych w środowisku węglowodorowym i teoretyczne podstawy wiedzy o właściwościach węglowodorów jako rozpuszczalników, a także przeanalizowano stosowane techniki i metody oceny kompatybilności surowców naftowych. Przedstawiono testy bibułowe, od najprostszego testu plamkowego (spot test), opracowanego pierwotnie do badania obecności nierozpuszczalnych cząstek w asfaltach, oraz jego wariantów, po metody zautomatyzowane (analizator Porla). Porównano współczynniki charakteryzujące kompatybilność, pokazano sposób wyznaczania współczynników takich jak pvalue, równoważnik ksylenowy czy współczynniki Heithausa i ich wykorzystanie. W artykule omówiono również inne parametry opisujące model kompatybilności rop naftowych i ich składników, takie jak parametry rozpuszczalności, zdefiniowane jako liczba nierozpuszczalności $I_{N}$ (ang. insolubility number), będąca również miarą rozpuszczalności asfaltenów, oraz liczba rozpuszczalności mieszaniny $S_{B N}$ (ang. solubility blending number), określająca zdolność ropy do rozpuszczania asfaltenów.
\end{abstract}

Słowa kluczowe: ropa naftowa, kompatybilność, test plamkowy, p-value, równoważnik ksylenowy, liczba nierozpuszczalności, liczba rozpuszczalności.

ABSTRACT: Crude oil processed in refineries is a complex mixture of hydrocarbons in which some heteroorganic compounds are dissolved or suspended. These types of systems are usually characterized by some instability, associated with precipitation of multiphase structures depending on the chemical nature of the oil components. These phenomena affect the proper course of refinery processes. The formed suspensions, and consequently sediments, associated with a change in the chemical nature of the matrix (mixtures of hydrocarbons derived from petroleum), can block the refinery infrastructure - tanks and pipelines - as well as heat exchangers. These deposits can be transferred to the liquid phase only by increasing matrix polarity. Therefore, to prevent thermally irreversible peptization and sedimentation of asphaltene - resin structures and aggregates, it is necessary to assess the compatibility of processed oil as precisely as possible. When composing the charge, it is necessary to assess and test the compatibility of mixed crude oils. This work summarizes information on both the practical and the theoretical aspects of crude oil compatibility. The principles of petroleum classification, contemporary views on the construction of colloidal structures suspended in a hydrocarbon environment, theoretical basis of knowledge about the properties of hydrocarbons as solvents were discussed, and the techniques and methods used to assess the compatibility of petroleum raw materials were analyzed. Blotter tests are presented, from the simplest spot test, originally developed for testing the presence of insoluble particles in asphalt and its variants, to automated methods (the PORLA analyzer). Parameters characterizing compatibility are compared, the method of determining parameters such as the p-value, the xylene equivalent or the Heithaus coefficients and their use is presented. The article also discusses other parameters describing the petroleum compatibility model and their components, such as solubility parameters, defined as the Insolubility Number (IN), which is also a measure of the solubility of the asphaltenes, and the solubility blending number Solubility Blending Number (SBN), determining the oil's ability to dissolve asphaltenes.

Key words: crude oil, compatibility, spot test, p-value, xylene equivalent, Insolubility Number, Solubility Blending Number.

Autor do korespondencji: W. Krasodomski, e-mail: wojciech.krasodomski@inig.pl

Artykuł nadesłano do Redakcji: 07.01.2020 r. Zatwierdzono do druku: 30.04.2020 r. 
Współczesne rafinerie ze względów ekonomicznych zazwyczaj przetwarzają mieszaninę rop z różnych źródeł, aby zapewnić optymalny asortyment produktów przy minimalizacji kosztów produkcji. Ponieważ przerabiane ropy mogą wykazywać odmienny skład chemiczny, stwarza to zagrożenie możliwością nieoczekiwanych interakcji pomiędzy obecnymi w nich składnikami. Takie interakcje mogą utrudnić lub wręcz uniemożliwić dalszy przerób wsadu skomponowanego bez wstępnej oceny możliwości mieszania konkretnych rop.

Zagrożenie to jest przyczyną specjalnego zainteresowania problemem badania kompatybilności dostępnych rop naftowych, stąd konieczność szczegółowego rozeznania zjawisk związanych z fizykochemią ciekłych mieszanin wieloskładnikowych, w tym rozpuszczania, solubilizacji, koagulacji czy strącania zawartych w nich składników. Należy tu zauważyć, że czynnikiem decydującym o stabilności mieszaniny rop jest obecność w nich asfaltenów - substancji nierozpuszczalnych w węglowodorach nasyconych. Jest zatem oczywiste, jak ważne jest możliwie szerokie poznanie rodzaju i właściwości substancji tworzących ropę naftową.

Ropa naftowa jest złożoną ciekłą mieszaniną składającą się w głównej mierze z różnego rodzaju węglowodorów - związków różniących się strukturą chemiczną, lecz zawierających w różnych proporcjach tylko węgiel i wodór. Obecne są w niej również niewielkie ilości innych grup związków organicznych zawierających siarkę (siarczki, disiarczki, tioetery itp.), tlen (np. alkohole, fenole, kwasy karboksylowe), azot (aminy, pirole itp.) oraz ich pochodne wiążące metale, takie jak wanad, nikiel, żelazo i miedź (np. kompleksy porfirynowe). Związki chemiczne zawarte w ropie różnią się także wielkością cząsteczek, począwszy od gazowego metanu, rozpuszczonego w surowej ropie, do złożonych struktur, jakimi są żywice i asfalteny, których masy osiągają średnio 750 daltonów (Mullins et al., 2007), dodatkowo wykazujących zdolność do tworzenia wielkocząsteczkowych aglomeratów o masach rzędu kilku do kilkudziesięciu tysięcy daltonów.

Sposób utworzenia się ropy naftowej (Petroleum Formation) jest do dziś przedmiotem dyskusji naukowej. Zwolennicy abiogennego powstawania złóż ropy (Abiotic Oil Formation) uważają, że źródłem powstania ropy są bliżej nieokreślone przemiany chemiczne metanu czy węgla, przy katalitycznym współdziałaniu minerałów litosfery - substancji nieorganicznych. Przeważa jednak pogląd (Tissot i Welte, 1984; Petrowiki), że podstawowym materiałem, z którego powstała ropa naftowa, były substancje organiczne (węglowodany, lignina, białka i thuszcze) wytwarzane przez żywe organizmy, głównie morskie, osadzające się na dnie zbiorników wodnych (morza, oceany). Stąd w pierwszym etapie procesu zwanego diagenezą, przebiegającym w umiarkowanych warunkach temperatury i ciśnienia, przy udziale odpowiednich mikroorganizmów wytworzyła się substancja zwana kerogenem, która w porównaniu z ropą naftową, w którą się przekształciła, wykazywała znaczne różnice w podstawowym składzie elementarnym, co przedstawiono w tabeli 1.

Tabela 1. Porównanie składu kerogenu i ropy naftowej (Tissot i Welte, 1984; Dutton; Petrowiki)

Table 1. Comparison of kerogen and crude oil composition (Tissot and Welte, 1984; Dutton; Petrowiki)

\begin{tabular}{|c|c|c|}
\hline \multirow{2}{*}{ Pierwiastek } & Kerogen & Ropa naftowa \\
\cline { 2 - 3 } & $\mathbf{\%}(\mathrm{m} / \mathrm{m})$ & $\mathbf{\%}(\mathrm{m} / \mathrm{m})$ \\
\hline \hline $\mathrm{C}$ & $75-85$ & $84-86$ \\
\hline $\mathrm{H}$ & $4-11$ & $11-14$ \\
\hline $\mathrm{S}$ & $0,2-4,9$ & $0-6$ \\
\hline $\mathrm{N}$ & $0,4-3,9$ & $0-1$ \\
\hline $\mathrm{O}$ & $4,4-19$ & $0-2$ \\
\hline
\end{tabular}

Można tu zauważyć, że w wyniku przemian zachodzących podczas procesów katagenezy (przekształcenie się kerogenu w ropę naftową) wyraźnie wzrosła zawartość komponentów węglowodorowych kosztem związków tlenowych i azotowych (lipidów i białek z organizmów żywych). Zmieniła się również zawartość siarki. W zależności od warunków procesów katagenezy ropy naftowe zawierają współcześnie różne ilości węglowodorów parafinowych, izoparafinowych, naftenowych i aromatycznych, a także substancji wielkocząsteczkowych (maltenów i asfaltenów, często określanych wspólnie jako asfalty). Zawartość wyżej wymienionych substancji stanowi podstawę pierwszej klasyfikacji przemysłowej rop naftowych, zaproponowanej przez Lane'a i Gartona (Margosches 1945). Wykorzystano w niej pomiar gęstości pojedynczej frakcji destylatu odbieranego przy ciśnieniu atmosferycznym w zakresie temperatur $250^{\circ} \mathrm{C}$ do $275^{\circ} \mathrm{C}$. Ropy podzielono na cztery grupy (parafinową: $d<0,8251$, pośrednią: $d$ od 0,8587 do 0,8256 oraz - różniące się lepkością - grupę mieszaną i naftenową: $d>0,8602$ ). W 1935 r. klasyfikację rozszerzono, wykorzystując dodatkowo odpowiednie wartości gęstości frakcji tzw. ciężkiej (o zakresie temperatur wrzenia od $275^{\circ} \mathrm{C}$ do $300^{\circ} \mathrm{C}$ ), destylującej przy obniżonym ciśnieniu (40 mm Hg). Określono w ten sposób podział rop na dziewięć grup (tab. 2).

Współcześnie (El-Naggar et al., 2014) klasyfikacja ropy naftowej według składu chemicznego opiera się na zawartości komponentów we frakcji destylującej w temperaturze $250^{\circ} \mathrm{C}$ do $300^{\circ} \mathrm{C}$, przy czym wyróżnia się cztery grupy tych komponentów:

- parafiny o strukturze liniowej lub rozgałęzionej, w których stosunek liczby atomów $\mathrm{C} / \mathrm{H}$ jest bliski $1: 2$, a ich zawartość $\mathrm{w}$ ropach mieści się $\mathrm{w}$ granicach od $15 \%$ do $70 \%$;

- nafteny, o podobnej wartości stosunku $\mathrm{C} / \mathrm{H}$, które są węglowodorami zawierającymi struktury cykliczne, a ich zawartość w ropach waha się od $30 \%$ do $60 \%$; 
Tabela 2. Klasyfikacja rop naftowych - 1935 r. (Margosches, 1945)

Table 2. Petroleum classification - 1935 (Margosches, 1945)

\begin{tabular}{|c|c|c|c|c|}
\hline & & & Frakcja $1^{*}$ & Frakcja $2^{* *}$ \\
\hline Ropa & Frakcja $1^{*}$ & Frakcja $2^{* *}$ & $\begin{array}{l}\text { gęstość } \\
d_{60 F}^{60 F^{* * *}}\end{array}$ & $\begin{array}{c}\text { gęstość } \\
d_{60 F}^{60 F}\end{array}$ \\
\hline Parafinowa & parafinowa & parafinowa & $<0,8251$ & $<0,8762$ \\
\hline Parafinowo-pośrednia & parafinowa & pośrednia & $<0,8251$ & $0,9334-0,8767$ \\
\hline Pośrednio-parafinowa & pośrednia & parafinowa & $0,8597-0,8356$ & $<0,8762$ \\
\hline Pośrednia & pośrednia & pośrednia & $0,8597-0,8356$ & $0,9334-0,8767$ \\
\hline Pośrednio-naftenowa & pośrednia & naftenowa & $0,8597-0,8356$ & $>0,9340$ \\
\hline Naftenowo-pośrednia & naftenowa & pośrednia & $>0,8602$ & $0,9334-0,8767$ \\
\hline Naftenowa & naftenowa & naftenowa & $>0,8602$ & $>0,9340$ \\
\hline Parafinowo-naftenowa & parafinowa & naftenowa & $<0,8251$ & $>0,9340$ \\
\hline Naftenowo-parafinowa & naftenowa & parafinowa & $>0,8602$ & $<0,8762$ \\
\hline
\end{tabular}

${ }^{*}$ Frakcja 1: o zakresie temperatur wrzenia $250-275^{\circ} \mathrm{C}$, odbiór destylatu przy ciśnieniu atmosferycznym.

${ }^{* *}$ Frakcja 2: o zakresie temperatur wrzenia $275-300^{\circ} \mathrm{C}$; odbiór destylatu pod obniżonym ciśnieniem $40 \mathrm{mmHg}$.

${ }^{* * *} 60$ stopni Fahrenheita odpowiada $15,56^{\circ} \mathrm{C}$.

- aromaty, o niższej wartości stosunku $\mathrm{C} / \mathrm{H}$, które charakteryzują się obecnością mono- lub policyklicznych struktur aromatycznych, a ich ilość w ropach mieści się w zakresie od 3\% do 30\%;

- związki wielkocząsteczkowe i asfalty, obecne w większości rop średnio w ilości $\sim 6 \%$, o wartości stosunku $\mathrm{C} / \mathrm{H}$ bliskiej $1: 1$, w których można wyróżnić grupy maltenów (żywic) i asfaltenów.

Różnice składu chemicznego rop mają bezpośrednie odzwierciedlenie w gęstości konkretnej ropy naftowej, parametrze stosunkowo łatwym do analitycznego oznaczenia. $Z$ tego

Tabela 3. Klasyfikacja jakościowa rop naftowych w zależności od zawartości siarki i gęstości API (Harraz, 2016; The Engineering ToolBox)

Table 3. Classification of crude oil quality depending on sulfur content and API density (Harraz, 2016; The Engineering ToolBox)

\begin{tabular}{|c|c|c|c|}
\hline \multirow{2}{*}{$\begin{array}{l}\text { Typ ropy } \\
\text { naftowej }\end{array}$} & \multirow{2}{*}{ Gęstość API } & \multirow{2}{*}{ Charakter } & $\begin{array}{c}\text { Zawartość } \\
\text { siarki }\end{array}$ \\
\hline & & & $\%(m / m)$ \\
\hline $\begin{array}{l}\text { Ultralekka, } \\
\text { tzw. stabilny } \\
\text { kondensat } \\
\text { gazowy }\end{array}$ & $>50$ & - & $<0,1$ \\
\hline \multirow{3}{*}{ Lekka } & \multirow{3}{*}{$35-55$} & słodka & $<0,5$ \\
\hline & & średnio kwaśna & $0,5-1,0$ \\
\hline & & kwaśna & $>1,0$ \\
\hline \multirow{3}{*}{ Średnia } & \multirow{3}{*}{$20-40$} & słodka & $<0,5$ \\
\hline & & średnio kwaśna & $0,5-1,0$ \\
\hline & & kwaśna & $>1,0$ \\
\hline \multirow{3}{*}{ Ciężka } & \multirow{3}{*}{$0-26$} & słodka & $<0,5$ \\
\hline & & średnio kwaśna & $0,5-1,0$ \\
\hline & & kwaśna & $>1,0$ \\
\hline
\end{tabular}

względu gęstość w temperaturze $15^{\circ} \mathrm{C}$ oraz zawartość siarki stały się podstawą klasyfikacji rop zgodnie z zaleceniami API (Amerykańskiego Instytutu Naftowego), przedstawionej w tabeli 3 i na rysunku 1.

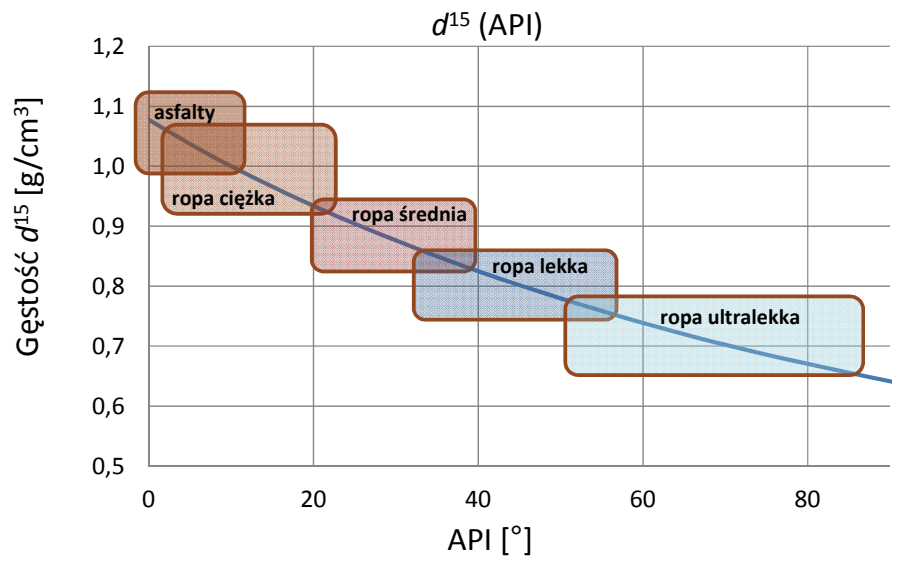

Rys. 1. Klasyfikacja jakościowa rop naftowych w zależności gęstości API i gęstości $d^{15}$ (Harraz, 2016; The Engineering ToolBox) Fig. 1. Crude oil quality classification depending on API density and $d^{15}$ density (Harraz, 2016; The Engineering ToolBox)

Znacznie większą ilość informacji technologicznych niż klasyfikacja API niesie system klasyfikacji rop stosowany przez jednego z większych eksporterów ropy naftowej - Rosję. W systemie tym, opisanym w normie GOST 51858 (GOST R 51858-2002), ropę naftową umownie oznacza się w formie następującego zapisu:

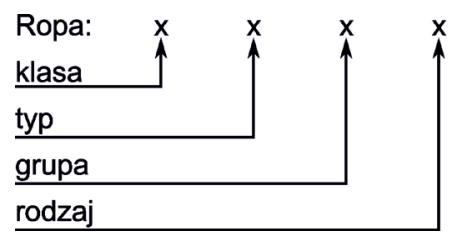

GOST 51858 
Wyróżniane są cztery klasy rop:

1 - niskosiarkowa (do 0,6\% S);

2 - siarkowa $(0,61-1,80 \% \mathrm{~S})$;

3 - wysokosiarkowa (1,81-3,5\% S);

4 - o bardzo wysokiej zawartości siarki (>3,5\% S).

W każdej klasie wyróżniono pięć typów - w zależności od gęstości w temperaturze $20^{\circ} \mathrm{C}\left(\mathrm{kg} / \mathrm{m}^{3}\right)$ :

0 - nadzwyczaj lekka $\left(d^{20} \leq 830,0 \mathrm{~kg} / \mathrm{m}^{3}\right)$;

1 - lekka $\left(830,1 \mathrm{~kg} / \mathrm{m}^{3} \leq d^{20} \leq 850,0 \mathrm{~kg} / \mathrm{m}^{3}\right)$;

2 - średnia $\left(850,1 \mathrm{~kg} / \mathrm{m}^{3} \leq d^{20} \leq 870,0 \mathrm{~kg} / \mathrm{m}^{3}\right)$;

3 - ciężka $\left(870,1 \mathrm{~kg} / \mathrm{m}^{3} \leq d^{20} \leq 895,0 \mathrm{~kg} / \mathrm{m}^{3}\right)$;

4 - asfaltowa $\left(d^{20}>895,0 \mathrm{~kg} / \mathrm{m}^{3}\right)$.

Klasyfikacja wydziela trzy grupy charakteryzujące stopień przygotowania ropy do przetwarzania na podstawie zawartości wody w ropie (grupy 1 i 2 zawierają poniżej 0,5\% wody, a grupa 3 poniżej 1\%) oraz zawartości chlorków nieorganicznych (odpowiednio < $100 \mathrm{mg} / \mathrm{l},<300 \mathrm{mg} / \mathrm{l}$ i $<900 \mathrm{mg} / \mathrm{l}$ ).

Rodzaj w opisie ropy wskazuje na zawartość siarkowodoru wyrażoną w mg/l (1: <20 mg/1, 2: <100 mg/l).

Podstawowym problemem w procesach przetwarzania rop naftowych, a zwłaszcza ich mieszanek, jest obecność substancji wielkocząsteczkowych - asfaltenów, ponieważ podczas mieszania rop mogą występować zjawiska ich koalescencji, solubilizacji i wytrącania w postaci odrębnych faz. Wielkocząsteczkowe asfalteny definiowane są zwykle jako substancje wytrącane $\mathrm{z}$ rop po ich zmieszaniu $\mathrm{z} n$-heptanem, modelującym zachowanie się węglowodorów parafinowych. Istotnym zagadnieniem staje się zatem możliwość oceny kompatybilności konkretnych rop naftowych przed wprowadzeniem do przerobu ich mieszanin o różnych zawartościach węglowodorów nasyconych.

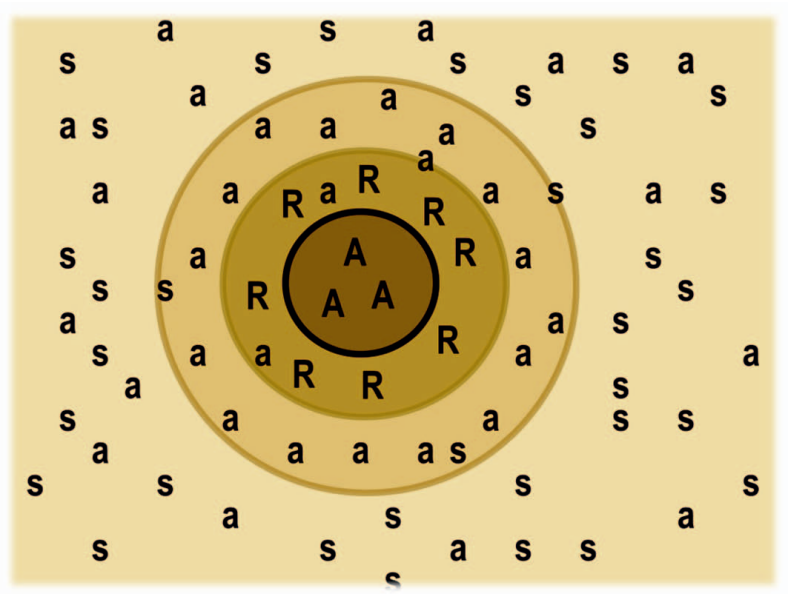

Rys. 2. Struktura miceli asfaltenów zdyspergowana i zawieszona w środowisku ciekłych węglowodorów naftowych (s - nasyconych i a - aromatycznych); A - asfalteny, a - węglowodory aromatyczne, $\mathrm{R}$ - żywice, $\mathrm{s}$ - węglowodory nasycone

Fig. 2. Structure of asphaltene micelles, dispersed and suspended in a matrix of liquid petroleum hydrocarbons ( $\mathrm{s}-$ saturated and $\mathrm{a}-$ aromatic). $\mathrm{A}$ - asphalthenes, $\mathrm{a}$ - aromatics, $\mathrm{R}$ - resins, $\mathrm{s}-$ saturates
Fizykochemiczny model struktury zawieszonych w ropie aglomeratów substancji wielkocząsteczkowych (rys. 2) opisano w monografii Irwina Wiehe'a (Wiehe, 2008).

W centrum molekuły dyspersji znajduje się rdzeń asfaltenowy A, otoczony polarnymi cząstkami żywic R, spełniającymi rolę dyspergatora kontaktującego się z węglowodorami aromatycznymi (a). Całość struktury dopełniają węglowodory nasycone s - parafiny i nafteny, które, jak wskazano wyżej, stanowią główny składnik większości rop naftowych.

W rzeczywistych strukturach molekuły tworzące warstwy wokół cząstki asfaltenów, tj. dyspergator oraz cząstki węglowodorów, mogą ulegać pewnemu wymieszaniu, zmieniając właściwości dyspersji, co wiąże się ze zmianami stopnia asocjacji i może wpływać na utratę równowagi fazowej i agregację cząstek koloidu. Efektem tego mogą być nieoczekiwane procesy wytrącania się osadów - flokulacja - w przypadku zmian składu fazy ciekłej wokół zdyspergowanych cząstek asfaltenów, zachodzące zwłaszcza podczas mieszania różnych gatunków rop.

Gdy nastąpi flokulacja asfaltenów w toku pierwotnych procesów rafineryjnych, powstające osady blokują przepływy strumieni w urządzeniach technologicznych do przeróbki ropy naftowej, np. w instalacji destylacji rurowo-wieżowej DRW, takich jak wymienniki ciepła czy piece rurowe, a także utrudniają kontakt medium ze złożem katalizatora we wtórnych procesach przerobu ropy. Zjawisko to, w odróżnieniu od znanego osadzania się $n$-parafin, jest termicznie nieodwracalne i powoduje poważne problemy związane z koniecznością okresowego usuwania powstałych osadów/zanieczyszczeń oraz z obecnością różnego rodzaju zawiesin i wytrąceń $\mathrm{w}$ produktach przerobu ropy.

W związku z powyższym bardzo ważne są sposoby oceny kompatybilności rop naftowych przed ich zmieszaniem, mające na celu ocenę ich skłonności do tworzenia układów dwufazowych, wytrącania po zmieszaniu stałej fazy asfaltenowej, a także stabilności rop podczas przechowywania. Metodyka takiej oceny obecnie nie jest jeszcze w pełni opracowana, co świadczy o złożoności problemu.

Najprostszym, a zarazem najstarszym sposobem badania powstawania/obecności zawiesiny jest punktowy test bibułowy, opracowany pierwotnie do badania obecności nierozpuszczalnych cząstek w asfaltach (Oliensis, 1933). To oznaczenie, często nazywane testem punktowym Oliensisa, jest badaniem, które wykorzystuje właściwość selektywnej rozpuszczalności niektórych węglowodorów w odniesieniu do składników asfaltu. Jako rozpuszczalnik zwykle wykorzystuje się ciężką benzynę (Materials Testing, Field Manual No. 5-472, 2009). $\mathrm{W} 10 \mathrm{ml}$ tego rozpuszczalnika rozpuszcza się, dokładnie mieszając, 2 g badanego asfaltu i kroplę tak uzyskanej mieszaniny umieszcza na kawałku bibuły filtracyjnej Whatman nr 50. 
Po 5 minutach wykonuje się wizualną obserwację utworzonej plamy. Jeśli plama jest żółtawo-brązowa z ciemniejszym jądrem, test jest pozytywny (następuje wytrącenie). Jeśli plama ma kolor jednolicie brązowy, test jest negatywny. Ponieważ wytrącanie asfaltenów może następować po upływie dłuższego czasu, próbówkę pozostawia się na 24 godziny, a następnie powtarza się test. Jeśli ponownie obserwuje się plamę z ciemniejszym jądrem, wynik testu jest pozytywny. Wynik negatywny wskazuje, że próbka jest materiałem jednorodnym, z którego w warunkach badania nie są wytrącane asfalteny. Zastosowanie zamiast ciężkiej benzyny mieszanin $n$-heptanu z toluenem w różnej proporcji jako rozpuszczalnika umożliwiło dokładniejszą ocenę obecności asfaltenów w ropach i ciężkich frakcjach naftowych. Należy również zauważyć, że podobną technikę badania, przy prowadzeniu testu w temperaturze $100^{\circ} \mathrm{C}$, zastosowano w normie ASTM D 4740-14, dotyczącej oceny czystości i kompatybilności paliw naftowych.

Kolejnym badaniem umożliwiającym ocenę kompatybilności ropy lub frakcji naftowej jest oznaczenie tzw. liczby peptyzacji (ang. p-value). Test polega na miareczkowaniu mieszanin badanej próbki ropy rozpuszczalnikiem aromatycznym (ksylen, toluen) z zastosowaniem najczęściej $n$-heptanu jako tzw. nierozpuszczalnika. Technika ta została wykorzystana w analizatorze Porla, opracowanym w fińskiej firmie Neste Oil (Orea et al., 2015; Finnish Measurement Systems Ltd). Aparat wykonuje zwykle miareczkowanie mieszanin zawierających trzy różne poziomy rozpuszczalnika aromatycznego do momentu rozpoczęcia wytrącania i wyznacza metodą najmniejszych kwadratów zależność współczynnika flokulacji, będącego funkcją zawartości rozpuszczalnika aromatycznego, w mieszaninach od odwrotności sumy rozpuszczalnika i nierozpuszczalnika. Uzyskuje się przy tym w zautomatyzowany sposób wartości parametrów kompatybilności $I_{N}$ (insolubility number) i $S_{B N}$ (solubility blending number).

Procedura przedstawiona w pracy Orei et al. (2015) została oparta na zasadach opisanych przez Heithausa (1962). Polegała ona na sporządzeniu trzech roztworów, zawierających odpowiednio 1,0 g; 2,0 g i 3,0 g próbki ropy oraz po 2,0 ml rozpuszczalnika aromatycznego (toluenu). Przy termostatowaniu próbki w temperaturze $25,0 \pm 0,1^{\circ} \mathrm{C}$ i ciągłym mieszaniu dodawano ze stałą prędkością, po kropli, odczynnik wytrącający, jakim był $n$-heptan. Początek flokulacji oceniano wizualnie, poprzez obserwację mikroskopową charakterystycznej plamki na bibule filtracyjnej, lub automatycznie (z zastosowaniem detektora rozproszenia światła) (Vilhunen i Waldvogel, 2010).

Przeprowadzone pomiary umożliwiły wyznaczenie wartości współczynników Heithausa $\left(P_{a}\right.$ i $\left.P_{O}\right)$ na podstawie analogicznych krzywych jak w przypadku metody Porla. Współczynnik $P$ określa skłonność asfaltenów do tworzenia stabilnej dyspersji z maltenami. Wartość $P_{a}$ zawiera się pomiędzy 0 (brak dyspergowania) a 1 (asfalteny łatwo dyspergują w środowisku maltenów) $\left(P_{a}=1-F R_{\max }\right)$. Wartość $F R_{\max }$ odpowiada punktowi przecięcia wyznaczonej prostej z osią współczynnika flokulacji. Parametr $P_{O}$ określa zdolność frakcji maltenowej do dyspergowania asfaltenów i jest ściśle związany z obecnością węglowodorów nasyconych, aromatycznych oraz żywic w badanej próbce. Wysoka wartość tego parametru wskazuje na dobre właściwości dyspergujące środowiska. Ogólną zdolność środowiska do peptyzacji asfaltenów określa parametr $P=P_{O} /\left(1-P_{a}\right)$. Może on przyjmować wartości od 0 do 10 . Próbki o wartościach mniejszych niż 1 określa się jako niestabilne, natomiast powyżej 2 klasyfikuje się jako wysoko stabilne.

Badania związane z teoretycznymi aspektami właściwości rozpuszczalników, prowadzone przez Hildebranda (1981) oraz Hansena (2007), doprowadziły do wyznaczenia współczynnika rozpuszczalności, definiowanego jako pierwiastek kwadratowy z gęstości energii kohezji lub jako pierwiastek kwadratowy z ilorazu energii odparowania gazu idealnego $\left(E_{V}\right)$ oraz jego objętości molowej $(V)$. Wartość energii $E_{V}$ uzyskuje się przez pomniejszenie ciepła parowania $\Delta H_{V}$ o czynnik odpowiadający gazowi idealnemu $(R T)$ zgodnie z równaniem:

$$
E_{V}=\Delta H_{V}-R T
$$

a zatem współczynnik rozpuszczalności jest równy $\delta$ :

$$
\delta=\sqrt{\frac{E_{v}}{V}}
$$

Jako jednostkę miary przyjęto

$$
1 \text { hildebrand }=1 \mathrm{cal}^{1 / 2} \mathrm{~cm}^{3 / 2}=0,4888 \mathrm{MPa}^{1 / 2}
$$

W celu uwzględnienia różnych rodzajów oddziaływań składników rozpuszczalnika z substancją rozpuszczoną Hansen (1967) zaproponował wyodrębnienie trzech podstawowych oddziaływań molekuł rozpuszczalnika ze środowiskiem: potraktowanie parametru rozpuszczalności jako wektora o składowej dyspersyjnej $\delta_{d}$ (związanej z siłami Londona), składowej $\delta_{p}$, odpowiadającej za oddziaływania elektrostatyczne - polarne, oraz składowej $\delta_{H}$, odzwierciedlającej obecność wiązań wodorowych.

W efekcie wartość gęstości energii kohezji oblicza się na podstawie równania:

$$
\delta^{2}=\delta_{d}^{2}+\delta_{p}^{2}+\delta_{H}^{2}
$$

Pozwala to w stosunkowo prosty sposób oszacować wartość parametru $\delta$ w przypadku cząsteczek, dla których wartość ciepła odparowania da się oznaczyć lub obliczyć. Jednak najczęściej w przypadku substancji zawieszonej w formie koloidów - a takim przypadkiem jest zawiesina asfaltenów w ropie naftowej - parametr ten wyznacza się doświadczalnie na podstawie szeregu obserwacji. 
Głównym problemem charakteryzującym stabilność rop naftowych i ich mieszanin jest ocena ich zdolności do peptyzacji i utrzymywania w stanie koloidalnym obecnych w nich asfaltenów - substancji wielkocząsteczkowych nierozpuszczalnych w węglowodorach nasyconych, w szczególności w $n$-heptanie. Ten ostatni rozpuszczalnik standardowo przyjęto za podstawowy w badaniach kompatybilności rop, ponieważ umożliwia najdokładniejsze wydzielenie asfaltenów i oddzielenie ich od również wielkocząsteczkowej grupy związków, jakimi są malteny (żywice). W dalszych badaniach nad modelem kompatybilności rop naftowych i ich składników wykorzystano zaproponowane przez Wiehe'a i Kennedy'ego (US 5997723; Wiehe i Kennedy, 2000) parametry rozpuszczalności, zdefiniowane jako liczba nierozpuszczalności $I_{N}$ (ang. insolubility number), będąca również miarą rozpuszczalności asfaltenów, oraz liczba rozpuszczalności mieszaniny $S_{B N}$ (ang. solubility blending number), określająca zdolność ropy do rozpuszczania asfaltenów. Parametry te są powiązane z omówionymi wyżej współczynnikami kompatybilności następującymi równaniami:

$$
\begin{gathered}
I_{N} \equiv 100 \frac{\delta_{f}-\delta_{H}}{\delta_{T}-\delta_{H}} \\
S_{B N} \equiv 100 \frac{\delta_{\text {oil }}-\delta_{H}}{\delta_{T}-\delta_{H}}
\end{gathered}
$$

gdzie:

$\delta_{f}$ - współczynnik rozpuszczalności substancji koagulującej,

$\delta_{\text {oil }}-$ współczynnik rozpuszczalności ropy.

Pozostałe parametry odpowiadają współczynnikom rozpuszczalności toluenu $\delta_{T}$ i $n$-heptanu $\delta_{H}$. Jeśli w wyniku zmieszania z cieczą testującą, którą jest $n$-heptan, nie obserwuje się wydzielania osadów, wartość parametru $S_{B N}$ wynosi 100 i $I_{\mathrm{N}}$ wynosi 0 , a badana ropa nie zawiera asfaltenów.

Ogólnie stosowana procedura polega (np. Łosiew et al., 2016) na sprawdzeniu za pomocą $n$-heptanu jako czynnika strącającego asfalteny, czy badana próbka je zawiera, po czym oszacowuje się maksymalną ilość $n$-heptanu, którą można wprowadzić do próbki bez pojawienia się koloidalnej zawiesiny. Następnie przygotowuje się kilka roztworów badanej ropy, które mają różną zawartość toluenu (jako rozpuszczalnika asfaltenów), i do uzyskanych roztworów wprowadza się małymi porcjami $n$-heptan w celu wytrącenia asfaltenów. Główną trudnością w tym etapie oznaczania jest prawidłowa ocena ilości $n$-heptanu niezbędnego do rozpoczęcia procesu wytrącania osadu asfaltenów. W tym celu wykorzystuje się obserwację mikroskopową kropli mieszaniny (przy powiększeniu 100-200-krotnym) lub metodę wizualną, obserwując zachowanie się kropli mieszaniny na bibule.

W analogiczny sposób postępuje się z każdą badaną ropą naftową lub mieszaniną rop, uzyskując obraz zależności zawartości toluenu (rozpuszczalnika) niezbędnej do utrzymania asfaltenów w stanie zawiesiny od udziału objętościowego lub masowego badanej ropy naftowej. Dla uzyskanych punktów flokulacji wyznacza się metodą regresji liniowej odpowiednie wykresy zależności.

Na rysunku 3 pokazano przykładowe przebiegi tego rodzaju wykresów dla trzech różnych rop naftowych - od ciężkiej ropy (1) (o gęstości $d \approx 0,98 \mathrm{~g} / \mathrm{cm}^{3}$ ) o wysokiej lepkości do lekkiej ropy (3) ( $\left.d \approx 0,82 \mathrm{~g} / \mathrm{cm}^{3}\right)$ o niskiej zawartości asfaltenów (rzędu $\sim 0,3 \%$ ).

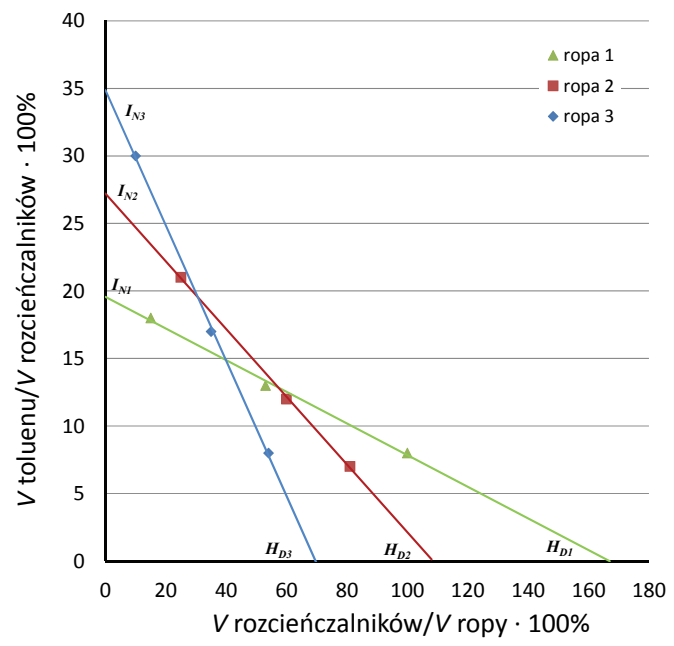

Rys. 3. Przykłady wyznaczania parametrów kompatybilności rop Fig. 3. Examples of determining oil compatibility parameters

Wartość liczby nierozpuszczalności $I_{N}$ odpowiada punktowi przecięcia uzyskanej prostej z osią Y udziału rozpuszczalnika aromatycznego (toluenu) w próbce. Jest ona miarą nierozpuszczalności asfaltenów ropy przy nieskończonym rozcieńczeniu (ilość ropy w mieszaninie $\mathrm{z}$ toluenem zmierza do zera). Jednocześnie wyznacza się parametr $H_{D}$, który odczytuje się jako wartość na osi X przy zerowej zawartości toluenu w próbce. Parametr $H_{D}$ określa ilość n-heptanu, przy której rozpoczyna się proces wytrącania asfaltenów z ropy nierozcieńczonej toluenem.

Wyznaczone w ten sposób parametry służą do obliczenia liczby rozpuszczalności mieszaniny $S_{B N}$ dla każdej badanej ropy, równej:

$$
S_{B N}=I_{N}\left[1+\frac{100}{H_{D}}\right]
$$

W przypadku konieczności przerobu mieszaniny $i$ różnych rop parametr $S_{B N m i x}$ mieszaniny można oszacować, wykorzystując równanie:

$$
S_{B N \operatorname{mix}}=\frac{\sum_{i=1}^{n} V_{i} \times S_{B N i}}{\sum_{i=1}^{n} V_{i}}
$$


gdzie:

$V_{i}$ - objętość ropy $i$ w mieszaninie rop,

$S_{B N i}-$ liczba rozpuszczalności ropy $i$.

W praktyce przyjmuje się, że podczas mieszania rop naftowych mogą pojawić się problemy niekompatybilności, w przypadku gdy maksymalna wartość parametru $I_{N}$ jednego ze składników mieszaniny jest większa od wartości parametru $S_{B N m i x}$ dla mieszaniny rop.

\section{Podsumowanie}

Należy stwierdzić, że problem kompatybilności przetwarzanych w rafinerii rop naftowych stanowi niezmiernie istotne zagadnienie, a jego rozwiązanie jest niezbędne do zapewnienia płynności działania instalacji rafineryjnych. Tworzące się zawiesiny, a w konsekwencji osady, związane ze zmianą charakteru chemicznego środowiska - mieszanki węglowodorów pochodzących z rop naftowych, mogą blokować infrastrukturę rafinerii - zbiorniki i rurociągi - a także wymienniki ciepła. Osady te można przeprowadzić do fazy ciekłej, jedynie zwiększając jej polarność. Aby zatem nie dopuścić do termicznie nieodwracalnych zjawisk peptyzacji i sedymentacji struktur i agregatów asfaltenowo-żywicznych, konieczna jest możliwie precyzyjna ocena kompatybilności przetwarzanych rop. Niestety mimo wielu prób omówionych powyżej dotychczas nie udało się opracować prostej i szybkiej metody jednoznacznie stwierdzającej ich kompatybilność, stąd popularność testów bibułowych w praktyce rafineryjnej, a także wciąż podejmowane próby wdrażania bardziej zaawansowanych metod badań.

Artykuł powstał na podstawie pracy statutowej pt.: Stabilność rop naftowych a osady obecne w zbiornikach magazynowych - praca INiG - PIB na zlecenie MNiSW; nr zlecenia: 0012/TA/2019, nr archiwalny: DK-4100-0012/2019.

\section{Literatura}

Abiotic Oil Formation. <http://www.petroleum.co.uk/abiotic-oi1-formation> (dostęp: 19.07.2019).

Dutton J.A. Elemental Analysis and Ternary Classification of Crude Oils. <https://www.e-education.psu.edu/fsc432/content/ elemental-analysis-and-ternary-classification-crude-oils $>$ (dostęp: 19.07.2019).

El-Naggar A.Y., El-Fadly A. A. , Mustafa Y., Ebiad A.S., 2014. Petroleum in View of its Classification, Assay and Analysis. International e-Publication. <http://www.isca.co.in/CHEM SCI/ book/ISBN 978-93-84648-05-3.pdf> (dostęp: 19.07.2019).

Finnish Measurement Systems Ltd. New Generation Porla analyser. $<$ https://www.biolab.com.tr/wp-content/uploads/upcp-product-file-uploads/PORLA\%20Datasheet.pdf> (dostęp: 19.07.2019).

Hansen C.M., 1967. The three dimensional solubility parameter and solvent diffusion coefficient. Copenhagen Danish Technical Press. $<$ https://hansen-solubility.com/contents/HSP1967-OCR. pdf> (dostęp: 8.08.2019).
Hansen C.M., 2007. Hansen Solubility Parameters. A User's Handbook. Second Edition. CRC Press.

Harraz H.Z., 2016. Lecture 1 - Crude Oil Quality. <https://www.slideshare.net/hzharraz/lecture-1-crude-oil-quality > (dostęp: 19.07.2019).

Heithaus J.J., 1962. Measurement and significance of asphaltene peptization. J. Inst. Pet. V., 48(458): 45-53. <https://books.google.pl/books/about/Journal_of the Institute_of_Petroleum.htm1?id=E05WAAAAMAAJ\&redir_esc=y $>($ dostęp: 8.08.2019).

Hildebrand J.H., 1981. A History of Solution Theory. Ann. Rev. Phys. Chem., 32: 1-23. <https://www.annualreviews.org/doi/ abs/10.1146/annurev.pc.32.100181.000245> (dostęp: 8.08.2019).

Łosiew A.P., Mogilniczenko M.A., Fiesan A.A., 2016. Kontrol smieszenija niesowmiestimych nieftiej w processach transportirowki i chranienija spiektrofotomietriczeskim mietodom. Truboprowodnyj transport: tieorija i praktika, 4(56). <https://www.rucont.ru/ efd/585438> (dostęp: 20.08.2019).

Margosches K.G., 1945. Classification of Crude Oils. $<$ http://delibra. bg.polsl.pl/Content/34691/BCPS_38664_1945_Journal-of-theInsti.pdf $>$ (dostęp: 19.07.2019).

Materials Testing, Field Manual No. 5-472, 2009. Bituminous mixtures 3-31. $<$ https://books.google.pl/books?id=JyIYBwAAQBAJ\&pg=SA3PA31\&lpg=SA3-PA31\&dq=oliensis + spot + test\&source=bl\&ots=iuuCXKz-f\&sig=ACfU3U08RlfgybqE1KnkUzvsBacmaHg1KA $\&$ hl $=$ pl\&sa $=$ X\&ved $=2$ ahUKEwjnleTym6XjAhUNp4sKHadUCr E4ChDoATAFegQIBRAB\# $\mathrm{v}=$ onepage $\& \mathrm{q}=$ oliensis $\% 2$ spot $\% 20$ test\&f=false $>$ (dostęp: 19.07.2019).

Mullins O.C., Sheu E.Y., Hammami A., Marshall A.G. 2007. Asphaltenes, Heavy Oils, and Petroleomics. Springer New York.

Oliensis G.L., 1933. A Qualitative Test for Determining the Degree of Heterogeneity of Asphalts. ASTM Proceeding, 33: 715-728. $<$ https://www.astm.org/DIGITAL_LIBRARY/STP/MMR/PAGES/ PRO1933-33.htm> (dostęp: 19.07.2019).

Orea M., Mujica Y., Diaz A., Lizardo G., Bruzual J., Bazdikian G., Árraga T., 2015. Dilution of heavy crude oils for pipeline transportation purposes: The asphaltene instability issue. Conference: Heavy Oil Latin American Conference (HOLA 2015): Bogotá Colombia. $<$ https://www.researchgate.net/publication/286937181_ Dilution_of_heavy_crude_oils_for_pipeline_transportation purposes_The_asphaltene_instability_issue? enrichId=rgreq98b55c6118d5fa7024c1a69299b0281f-XXX\&enrichSource $=Y 29$ 2ZXJQYWdlOzI4NjkzNzE4MTtBUzozMjgwOTU3ODI0NTczN DVAMTQ1NTIzNTUzODY4OQ\%3D\%3D\&el=1_x_2\&_esc=publicationCoverPdf> (dostęp: 19.07.2019).

Petroleum Formation. <http://www.petroleum.co.uk/formation> (dostęp: 19.07.2019).

Petrowiki. <https://petrowiki.org/Origin_of_petroleum> (dostęp: 19.07.2019).

The Engineering ToolBox. <https://www.engineeringtoolbox.com/ api-gravity-d_1212.html> (dostęp: 19.07.2019).

Tissot B.P., Welte D.H., 1984. Petroleum Formation and Occurrence. Springer-Verlag.

US 5997723, 1999. Process for Blending Petroleum Oils to Avoid Being Nearly Incompatible.

Vilhunen J., Waldvogel J., 2010. PORLA Heavy and Crude Oil Stability and Compatibility Analyzer as a Tool to Improve Profitability of Oil Industry. <http://www.acovexsystems.com/ wp-content/uploads/2014/06/vilhunenRIL2010.pdf> (dostęp: 19.07.2019).

Wiehe I.A., 2008. Process Chemistry of Petroleum Macromolecules. CRC Press, Taylor \& Francis Group.

Wiehe I.A., Kennedy R.J., 2000. The Oil Compatibility Model and Crude Oil Compatibility. Energy Fuels, 14(1): 56-59. DOI: 10.1021/ef990133+. 


\section{Akty prawne i normatywne}

ASTM D 4740-14 Standard Test Method for Cleanliness and

Compatibility of Residual Fuels by Spot Test.

GOST R 51858-2002 Crude petroleum. General specifications.

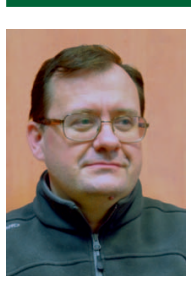

Dr Wojciech KRASODOMSKI

Adiunkt; kierownik Laboratorium Analiz Dodatków Instytut Nafty i Gazu - Państwowy Instytut Badawczy ul. Lubicz 25 A

31-503 Kraków

E-mail: wojciech.krasodomski@inig.pl

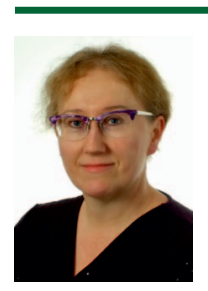

Dr inż. Beata ALTKORN

Adiunkt; kierownik Zakładu Analiz Naftowych Instytut Nafty i Gazu - Państwowy Instytut Badawczy ul. Lubicz 25 A

31-503 Kraków

E-mail: beata.altkorn@inig.pl

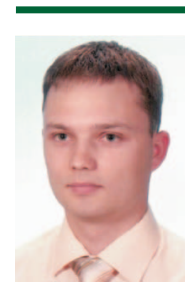

Mgr inż. Sławomir SZUFLITA

Asystent w Zakładzie Badania Złóż Ropy i Gazu Instytut Nafty i Gazu - Państwowy Instytut Badawczy ul. Lubicz 25 A

31-503 Kraków

E-mail: slawomir.szuflita@inig.pl

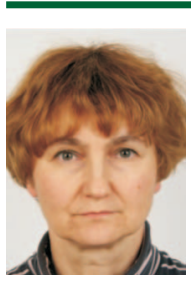

Mgr inż. Anna DUDA

Specjalista badawczo-techniczny w Zakładzie Paliw i Procesów Katalitycznych

Instytut Nafty i Gazu - Państwowy Instytut Badawczy ul. Lubicz $25 \mathrm{~A}$

31-503 Kraków

E-mail:anna.duda@inig.pl

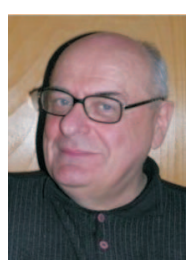

Prof. nzw. dr Michał KRASODOMSKI

Specjalista w zakresie chemii analitycznej ropy naftowej i produktów naftowych.

E-mail: kramich2013@gmail.com

\section{OFERTA BADAWCZA ZAKŁADU ANALIZ NAFTOWYCH}

- ropa naftowa i jej przerób:

" kompleksowe analizy rop naftowych dla potrzeb optymalizacii przerobu,

» wyznaczanie optymalnych parametrów procesu destylacii produktów odpadowych,

» optymalizacja pracy węztów odsalania i węztów aminowych;

- daktyloskopia chemiczna - realizacja ztożonych zadań, wymagających identyfikacji przyczyn problemu technicznego z zastosowaniem metod analizy chemicznej:

» badania identyfikacyjne osadów i zanieczyszczeń w zbiornikach magazynowych, cysternach, na instalacjach przemystowych, w rurociągach i wymiennikach ciepta,

» ustalanie źródet pochodzenia osadów powstatych w trakcie eksploatacii maszyn, urządzeń i pojazdów,

" identyfikacja i oznaczanie niepożądanych substancji w mediach ciekłych i gazowych,

" analiza parametrów procesowych oraz wsadów stosowanych na instalacjach w korelacij z tworzeniem się osadów, w tym z wykorzystaniem sieci neuronowych,

» ustalanie pochodzenia rozlewów, wylewów i zanieczyszczeń substancjami typu weglowodorów,

" badanie źródet naptywów do wód chtodniczych,

" optymalizacja pracy węztów usuwania węglowodorów ze ścieków;

kawerny solne - testy symulacyjne przechowywania rop i paliw;

chemia analityczna branży naftowej, w tym produktów pochodzenia biogennego:

» opracowywanie/walidacja nowych metod badań produktów,

» badania jakościowe produktów naftowych i pokrewnych, świeżych i z eksploatacii (certyfikat akredytacii AB 009); badania i doradztwo w zakresie Nomenklatury Scalonej CN;

orzecznictwo i opinie o jakości paliw i ptynów eksploatacyjnych, środków smarowych samochodowych i przemystowych oraz innych produktów naftowych, biopaliw, biokomponentów.

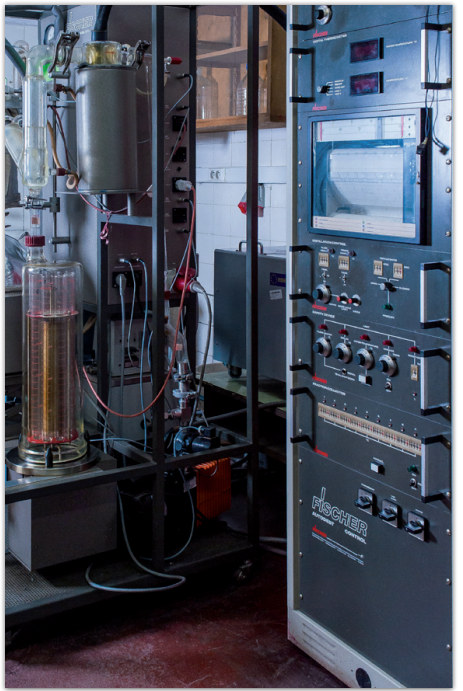

INSTYTUT NAFTY I GAZU

- Państwowy Instytut Badawczy 